\title{
Comparison of oxytocin/prostaglandin F-2 $\alpha$ interrelationships in cyclic and pregnant cows
}

\author{
T. J. Parkinson*, L. J. Jenner and G. E. Lamming \\ AFRC Research Group on Hormones and Farm Animal Reproduction, University of Nottingham, \\ School of Agriculture, Sutton Bonington, Loughborough, Leics, LE12 5RD, UK
}

\begin{abstract}
Summary. The secretion of prostaglandin (PG) $F-2 \alpha$ in response to intravenous injection of 100 i.u. oxytocin on Day 18 after oestrus was determined by measuring jugular venous concentrations of 13,14-dihydro-15-keto PGF-2 $\alpha$ (PGFM) in 7 pregnant, 6 cyclic and 2 inseminated non-pregnant heifers. Two other heifers received i.v. saline (controls). The immediate responses of pregnant heifers were smaller than in non-pregnant animals $(P<0.05)$, as were baseline concentrations in the post-response period $(P<0.05)$. Endometrial oxytocin receptor concentrations were higher in nonpregnant than pregnant heifers $(P<0.05)$, but PGFM response to oxytocin challenge was not correlated with oxytocin receptor concentration. Oxytocin receptor concentrations on Day 18 were positively correlated with those of plasma oestradiol on Day $17(P<0.01)$ and inversely with plasma progesterone concentrations on Day 18 $(P<0.01)$. These findings confirm that PGF-2 $\alpha$ secretion in response to oxytocin challenge is attenuated in pregnant animals on the 18th day after oestrus and that, while the prevailing steroid environment is of importance in inducing oxytocin receptor activity, the secretion of PGF- $2 \alpha$ is not subsequently limited by oxytocin receptor numbers.

The quantities of PGE-2, PGFM and PGF- $2 \alpha$ recovered in uterine flushings taken from heifers on Day 18 were greater in pregnant than other animals $(P<0.01$, $P<0.05, P<0.001$, respectively). Intrauterine concentrations of PGF-2 $\alpha$ and PGFM were not correlated with the plasma PGFM responses.
\end{abstract}

Keywords: cattle; early pregnancy; oxytocin; PGF-2 $\alpha$

\section{Introduction}

Luteolysis, which occurs in cyclic cattle 17-20 days after ovulation, does not occur in pregnant animals until gestation is completed. This inhibition of the process of luteolysis, initially dependent upon the presence of an embryo in the uterus 16-17 days after ovulation (Northey \& French, 1980), is now known to be due to the secretion of an embryonic antiluteolytic protein, bovine trophoblast protein-1 (bTP-1; Thatcher et al., 1989).

Uterine PGF-2 $\alpha$ secretion is inhibited in early pregnancy, as demonstrated by the lower uterine venous concentrations of PGF-2 $\alpha$ (Lukaszewska \& Hansel, 1980), lower peripheral concentrations of PGFM (Betteridge et al., 1984) and reduced amplitude of episodes of PGF secretion (Wolfenson et al., 1985) in pregnant compared with cyclic cows. The identification of bTP-1 has confirmed the key role of the embryo in attenuating PGF-2 $\alpha$ secretion, but has not clarified the mechanism by which this is achieved. Possibilities include interference with uterine synthesis of PGF- $2 \alpha$ or its

*Present address: Department of Veterinary Surgery, University of Bristol, Langford House, Langford, Bristol, BSI8 7DU, UK. 
release by oxytocin (see Flint $\&$ Sheldrick, 1982). In addition, pathways could be induced which result in protection of the corpus luteum from the effects of PGF-2 $\alpha$ (Nancarrow et al., 1982).

Pregnant ewes (Lacroix \& Kann, 1986) and ewes receiving intrauterine infusions of conceptus secretory proteins (CSP: Fincher et al., 1984) secrete less PGF-2 $\alpha$ in response to an oxytocin or oestradiol challenge than do cyclic animals. Similar results have been recorded for cows, on the 17 th to 19th days of pregnancy (Lafrance \& Goff, 1985) or on the 18th day of the oestrous cycle in animals pre-treated with intrauterine CSP (Knickerbocker et al., 1986). In the late luteal phase, endometrial oxytocin receptor concentrations of ewes (McCracken et al., 1984; Sheldrick \& Flint, 1985) and cows (Jenner et al., 1990) are higher than in animals at the equivalent stage of pregnancy, while pregnant ewes also have lower circulating (Sheldrick \& Flint, 1981; Webb et al., 1981) and luteal (Sheldrick \& Flint, 1983, 1984) concentrations of oxytocin than in the oestrous cycle.

It was therefore the purpose of this experiment to determine whether the reduced responsiveness of the bovine endometrium to administered oxytocin that has been shown, by the above reports, to occur at around the 18th day of pregnancy could be accounted for by a difference in uterine oxytocin receptor concentrations. It was also of interest to determine whether circulating steroid concentrations were correlated with the magnitude of the PGF responses to oxytocin challenge.

\title{
Materials and Methods
}

\begin{abstract}
Animals. Seventeen Hereford $\times$ Friesian heifers, approximately 18 months of age and weighing around $400 \mathrm{~kg}$, were used to compare the effects of oxytocin administration to cyclic and pregnant animals 18 days after oestrus. Oestrus was induced by a single intramuscular injection of $500 \mu \mathrm{g}$ cloprostenol (Estrumate; Coopers Animal Health Ltd, Crewe, UK) and its onset determined by frequent visual observation. Heifers which did not exhibit signs of oestrus were given a second injection of cloprostenol 11 days after the first, and oestrus was again determined by observation. Equal numbers of heifers were inseminated on the days of observed oestrus (pregnant and inseminated-not-pregnant) or were left unmated (cyclic and control groups).

Daily 5-ml blood samples were collected from the day of cloprostenol administration until the 3rd day after oestrus, then 3 samples/week until Day 17, with a final sample on Day 18, for plasma progesterone determination. These samples were collected to provide confirmation of the visual determinations of oestrus and to establish that normal luteal activity had subsequently occurred. Additional blood $(10 \mathrm{ml})$ was collected on Days 17 and 18 for plasma oestradiol measurement; these data were used for correlation with the prostaglandin responses obtained.

On Day 18, all heifers had a cannula placed in one jugular vein, then $10 \mathrm{ml}$ blood samples were collected every $10 \mathrm{~min}$ for a $1 \mathrm{~h}$ control period. After this, 100 i.u. oxytocin (Hoechst UK Ltd, Milton Keynes, UK), dissolved in $10 \mathrm{ml}$ sterile $0.9 \%(\mathrm{v} / \mathrm{w}) \mathrm{NaCl}$ solution, were infused via the jugular venous cannula over a 60 -sec period. Blood samples were then collected every $5 \mathrm{~min}$ for $30 \mathrm{~min}$ and every $10 \mathrm{~min}$ for a further $90 \mathrm{~min}$. The plasma was immediately separated by centrifugation and separate sub-samples frozen for PGFM and oxytocin assay. Two noninseminated heifers were given $10 \mathrm{ml}$ sterile saline alone, to form a vehicle control group, while the remaining 15 animals formed the treatment groups. All heifers were slaughtered within $3 \mathrm{~h}$ of completion of the period of blood sampling. After slaughter, the corpora lutea were described and weighed, the uterus removed and the uterine horns separated. The uterine horns of all heifers were flushed with $20 \mathrm{ml} 0.9 \%(\mathrm{v} / \mathrm{w}) \mathrm{NaCl}$ solution per horn, to determine whether inseminated animals were in fact pregnant and for measurement of PGE-2, PGF-2 $\alpha$ and PGFM concentrations. A $1 \mathrm{ml}$ sample of flushing medium was mixed with an equal volume of oximating reagent (see Kelly et al., 1986a) and left overnight for the reaction to proceed to completion. Endometrial tissue was also collected for estimation of oxytocin receptor concentrations by the method of Sheldrick \& Flint (1985) as modified for bovine tissue by Jenner et al. (1990). This method measures both occupied and unoccupied receptors (see Sheldrick \& Flint, 1986).
\end{abstract}

Hormone assays. Concentrations of PGE-2 and PGFM were measured as their methyl oximes, using the radioimmunoassays described by Kelly et al. (1986a), and those of PGF-2 $\alpha$ by the radioimmunoassay of Kelly et al. (1986b). A single assay was used in each case. Using ${ }^{3} \mathrm{H}$-labelled tracers, the limits of sensitivity of the assays for the methyl oxime of PGE-2 (PGE-2 MOX), PGFM MOX and PGF-2 $\alpha$ were 48,26 and $61 \mathrm{pg} / \mathrm{ml}$ respectively. Intra-assay coefficients of variation were $7 \cdot 1,8.7$ and $3.6 \%$ respectively. Plasma concentrations of oestradiol (Glencross et al., 1981; Glencross \& Pope, 1981), oxytocin (Sheldrick \& Flint, 1981), PGFM (Kaker et al., 1984) and progesterone (Hunter et al., 1986) were measured by radioimmunoassay. Assay sensitivity statistics are given in Table 1 .

Analysis of data. Plasma PGFM concentrations for the $60 \mathrm{~min}$ following oxytocin administration (immediate PGFM response) were subjected to analysis of variance, with respect to pregnancy status. Time after administration was used as a covariate, and the model also accounted for the effects of repeated sampling of cows. A response was 
Table 1. Characteristics of radioimmunoassays used for plasma hormone determinations

\begin{tabular}{lcccc}
\hline & Progesterone & PGFM & Oxytocin & Oestradiol \\
\hline Extraction efficiency & {$\left[{ }^{3} \mathrm{H}\right] 77 \cdot 7 \%$} & {$\left[{ }^{3} \mathrm{H}\right] 78 \cdot 3 \%$} & {$\left[{ }^{125} \mathrm{I}\right] 89 \%$} & {$\left[{ }^{3} \mathrm{H}\right] 71 \cdot 4 \%$} \\
Limit of sensitivity & $0 \cdot 23 \mathrm{ng} / \mathrm{ml}$ & $54 \cdot 2 \mathrm{pg} / \mathrm{ml}$ & $1 \cdot 69 \mathrm{pg} / \mathrm{ml}$ & $1 \cdot 41 \mathrm{pg} / \mathrm{ml}$ \\
$n$ & 5 & 8 & 5 & 1 \\
Interassay CV & $14 \cdot 2 \%$ & $15 \cdot 2 \%$ & $17 \cdot 8 \%$ & - \\
Intra-assay CV & $6.3 \%$ & $7 \cdot 7 \%$ & $6 \cdot 3 \%$ & $6 \cdot 9 \%$ \\
\hline
\end{tabular}

considered to have occurred when PGFM concentrations were increased by three times the s.e.m. of the control period mean and sustained at that level for at least two subsequent samples. When responses occurred, the amplitude and area under the curve were measured, and the number of samples between oxytocin administration and (a) the first rise in PGFM concentrations and (b) the maximum PGFM concentrations were determined. The mean concentrations in the final $60 \mathrm{~min}$ of the experiment (post-response period) were also calculated.

Data for the plasma concentrations of oestradiol on Days 17 and 18, progesterone concentrations on Day 18 and prostaglandin concentrations in uterine flushings, were subjected to analysis of variance. Pregnancy status was used as a factor in all analyses, with day relative to that of oestrus also used in analysing oestradiol data. The side of the uterus relative to the corpus luteum was the second factor in analysing uterine prostaglandin concentration data. Correlation and regression coefficients of the PGFM responses with uterine oxytocin receptor and plasma steroid concentrations were also calculated.

\section{Results}

Peripheral plasma oxytocin concentrations were close to the limit of assay sensitivity during the control period, but were increased to above $100 \mathrm{pg} / \mathrm{ml}$ for $20.8 \pm 1.3 \mathrm{~min}$ after 100 i.u. oxytocin had been administered into the jugular vein. No such increase occurred in saline-treated (control) animals.

Jugular venous plasma PGFM concentrations were similar in pregnant $(92.4 \pm 6.5 \mathrm{pg} / \mathrm{ml})$ and non-pregnant $(113.3 \pm 10 \cdot 1 \mathrm{pg} / \mathrm{ml})$ animals during the control period. Control animals showed no increase in PGFM concentrations after saline administration. Of the heifers that received oxytocin, mean plasma PGFM concentrations in the first $60 \mathrm{~min}$ after oxytocin administration were significantly greater in non-pregnant than pregnant animals, when the effect of the covariate, time, was included $(P<0.05)$. This finding is illustrated in Fig. 1, which includes fitted quadratic regression lines to define trends in the data. Differences between the mean amplitude of immediate responses in pregnant and non-pregnant heifers were not significant and much variation occurred within groups of animals (see Fig. 2). There were no significant differences between groups in the time between oxytocin administration and either the onset or peak of the PGFM response. Mean PGFM concentrations during the final $60 \mathrm{~min}$ of sampling were significantly higher in non-pregnant heifers $(163.9 \pm 21.0 \mathrm{pg} / \mathrm{ml})$ than in pregnant animals $(98.8 \pm 11.8 \mathrm{pg} / \mathrm{ml} ; P<0.05)$.

Endometrial oxytocin receptor concentrations on Day 18 were higher in non-pregnant than pregnant heifers $(P<0.05$; Fig. 3). Mean plasma oestradiol concentrations were higher in cyclic heifers than in other groups on both Days 17 and $18(P<0.05)$, but differences in progesterone concentrations were not significant $(0 \cdot 10>P>0.05)$. The magnitude of the PGFM responses was not correlated with either the plasma steroid concentrations on Days 17 and 18, or with endometrial oxytocin receptor concentrations on Day 18. Endometrial oxytocin receptor concentrations showed a significant positive correlation with those of plasma oestradiol on Day $17(P<0.01$; Fig. 4) and an inverse relationship with plasma progesterone concentrations on Day $18(P<0.01$; Fig. 5). When combined in a partial regression expression, the inclusion of progesterone concentrations on Day 18 provided no better explanation of the data than did Day-17 oestradiol concentrations alone. No other significant correlations were noted. 


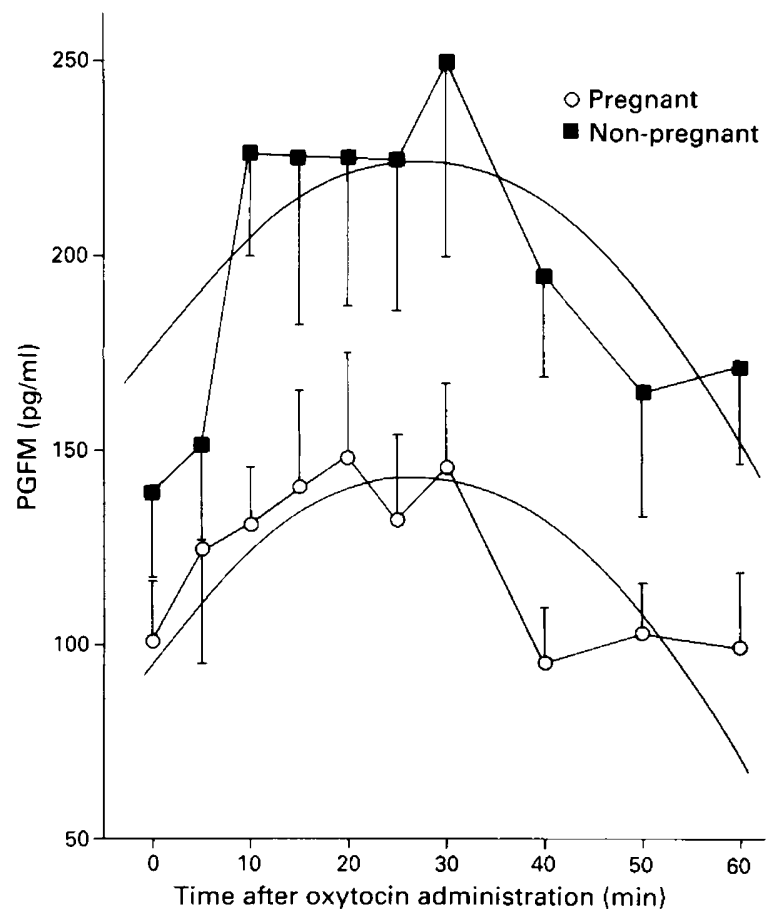

Fig. 1. Mean ( \pm s.e.m.) plasma PGFM concentrations of pregnant $(N=7)$ and non-pregnant $(\mathrm{N}=8)$ heifers in the first $60 \mathrm{~min}$ after oxytocin administration. Overall mean values are lower in pregnant and non-pregnant animals $(P<0.05)$. The intercept term of the fitted regression lines is also significantly lower $(P<0.01)$ in pregnant $\left(p=95.0+3.66 t-0.0674 t^{2}\right)$ than in non-pregnant $\left(p=175 \cdot 7+3.66 t-0.0674 t^{2}\right)$ heifers; where $p=$ plasma PGFM concentration $(\mathrm{pg} / \mathrm{ml})$ and $t=$ time in min after oxytocin administration.

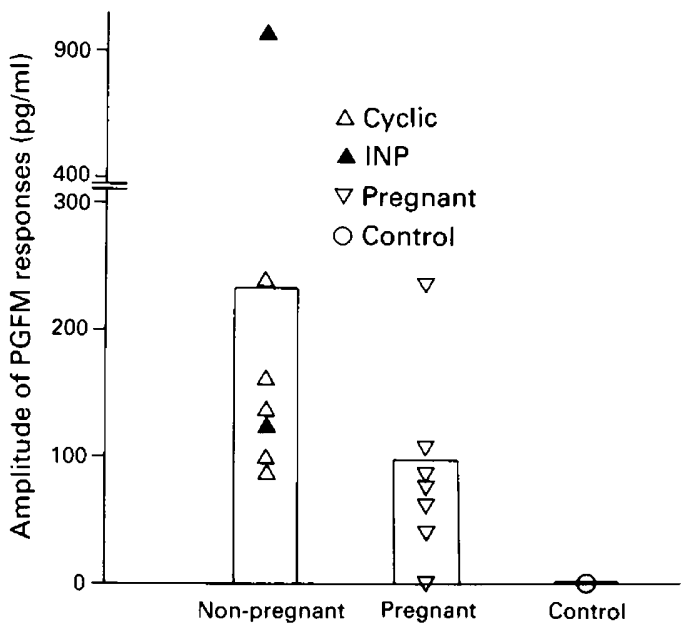

Fig. 2. Amplitudes of mean and individual PGFM responses to i.v. oxytocin administration in cyclic, pregnant, inseminated not-pregnant (INP) and control heifers. Differences between groups are not significant. 


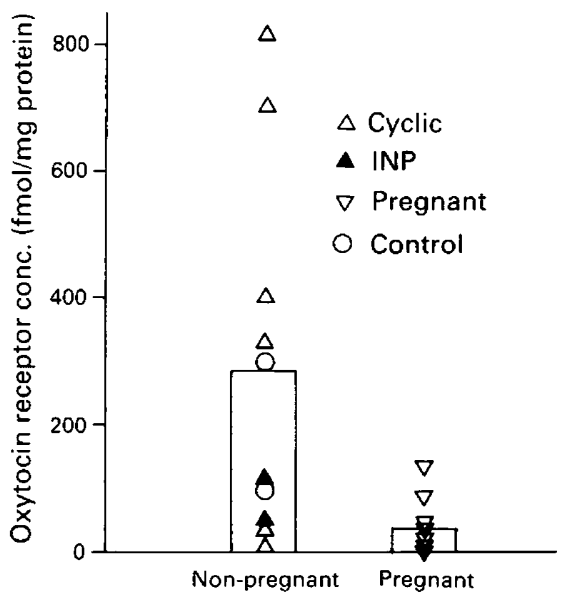

Fig. 3. Mean and individual endometrial oxytocin receptor concentrations in cyclic, pregnant, inseminated not-pregnant (INP) and control heifers on the 18th day of pregnancy or the oestrous cycle. Values in pregnant heifers are significantly lower than in non-pregnant animals $(P<0.05)$.

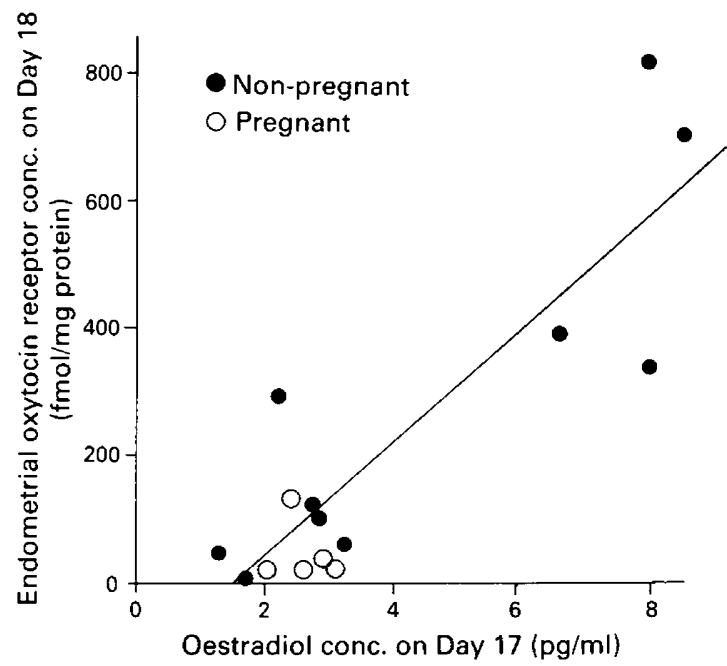

Fig. 4. Correlation between jugular venous plasma concentrations of oestradiol-17 $\beta$ on Day 17 and endometrial oxytocin receptor concentrations on Day 18 in pregnant and non-pregnant heifers $(r=0.875 ; P<0.01)$.

Mean quantities of PGF-2 $\alpha$, PGFM and PGE-2 in uterine flushings are given in Table 2. The amount of PGFM was greater in flushings from pregnant heifers than from other groups $(P<0.05)$; differences between uterine horns and between the non-pregnant groups were not significant. Quantities of PGF-2 $\alpha$ and PGE-2 were also higher in pregnant heifers than others $(P<0.001, P<0.01)$, but again there were no differences between the uterine horns or the non-pregnant groups. The ratio of PGFM to PGF-2 $\alpha$ tended to be higher in non-pregnant than pregnant animals $(0 \cdot 239: 1$ versus $0 \cdot 169: 1 ;$ N.S. $)$. 


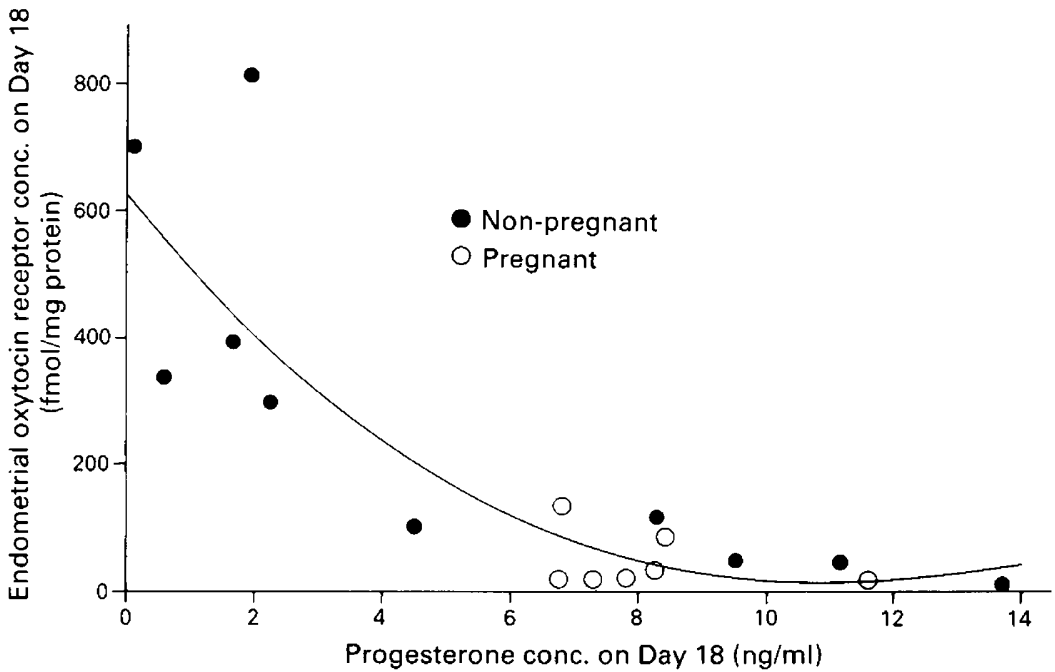

Fig. 5. Correlation between jugular venous plasma concentrations of progesterone and endometrial oxytocin receptor concentrations on Day 18 in pregnant and non-pregnant heifers $(r=-0.865 ; P<0.01)$.

Table 2. Mean ( \pm s.e.m.) quantities of PGF-2 $\alpha$, PGFM and PGE-2 in uterine flushings collected from the horn ipsilateral or contralateral to the corpus luteum of heifers on the 18th day of the oestrous cycle or pregnancy

\begin{tabular}{|c|c|c|c|c|}
\hline \multirow[b]{2}{*}{ PG } & \multirow[b]{2}{*}{ Group } & \multicolumn{3}{|c|}{ Prostaglandin content (ng/flushing) } \\
\hline & & $\begin{array}{l}\text { No. of } \\
\text { heifers }\end{array}$ & Ipsilateral horn & Contralateral horn \\
\hline PGF-2 $\alpha$ & $\begin{array}{l}\text { Cyclic } \\
\text { INP† } \\
\text { Control } \\
\text { Pregnant }\end{array}$ & $\begin{array}{l}6 \\
2 \\
2 \\
7\end{array}$ & $\begin{array}{c}24 \cdot 72 \pm 3.04 \\
21 \cdot 20 \pm 3.48 \\
22 \cdot 48 \pm 0.96 \\
188.08 \pm 22 \cdot 36^{* * *}\end{array}$ & $\begin{array}{c}26 \cdot 84 \pm 7 \cdot 20 \\
17 \cdot 20 \pm 1.08 \\
29 \cdot 24 \pm 1 \cdot 16 \\
224 \cdot 32 \pm 49 \cdot 24^{* * *}\end{array}$ \\
\hline PGFM & $\begin{array}{l}\text { Cyclic } \\
\text { INPt } \\
\text { Control } \\
\text { Pregnant }\end{array}$ & $\begin{array}{l}6 \\
2 \\
2 \\
7\end{array}$ & $\begin{array}{c}5.88 \pm 1.04 \\
4.44 \pm 0.36 \\
5.08 \pm 0.84 \\
18.44 \pm 5.08^{*}\end{array}$ & $\begin{array}{c}6 \cdot 76 \pm 1.40 \\
5 \cdot 72 \pm 0 \cdot 16 \\
6.36 \pm 1 \cdot 04 \\
14.36 \pm 1 \cdot 16^{*}\end{array}$ \\
\hline PGE-2 & $\begin{array}{l}\text { Cyclic } \\
\text { INP† } \\
\text { Control } \\
\text { Pregnant }\end{array}$ & $\begin{array}{l}6 \\
2 \\
2 \\
7\end{array}$ & $\begin{array}{c}11 \cdot 00 \pm 2 \cdot 04 \\
13 \cdot 36 \pm 1 \cdot 12 \\
9 \cdot 60 \pm 1 \cdot 32 \\
78 \cdot 16 \pm 21 \cdot 52^{* *}\end{array}$ & $\begin{array}{c}8.76 \pm 0.60 \\
15 \cdot 80 \pm 4.76 \\
17.32 \pm 8 \cdot 48 \\
66.44 \pm 14.72 * *\end{array}$ \\
\hline
\end{tabular}

Mean concentrations are different from values in cyclic animals as indicated: ${ }^{*} P<0.05,{ }^{* *} P<0.01,{ }^{* * *} P<0.001$. Differences between horns and between cyclic, INP and control groups are not significant.

†Inseminated, but not pregnant when slaughtered.

\section{Discussion}

The results of this experiment indicate that uterine secretion of PGF-2 $\alpha$, as determined by peripheral plasma PGFM concentrations, is significantly attenuated in heifers on the 18th day of pregnancy, 
in comparison to animals at the equivalent stage of the cycle. The immediate PGFM response, as defined by PGFM concentrations in the first $60 \mathrm{~min}$ after oxytocin challenge, was of lower overall mean value in pregnant than cyclic animals $(P<0.05)$ and baseline concentrations in the postresponse period were also reduced $(P<0.05)$. However, there was much individual variation in responses, such that differences of mean response amplitude between pregnant and non-pregnant animals were not significant. These results are similar to those of McCracken et al. (1984) for the ewe and of Lafrance \& Goff (1985) for the heifer; both studies showed a significant attenuation of the responses to oxytocin administration in pregnant animals.

The variability of the PGFM responses could be due in part to the refractory period that occurs after oxytocin has stimulated an episode of PGF-2 $\alpha$ release (Sheldrick \& Flint, 1986). Thus, if the exogenous oxytocin were given shortly after an endogenous episode of oxytocin secretion had occurred, an attenuated response would occur. However, when heifers were given oestradiol on Days 17-20, in a similar challenge experiment (Thatcher et al., 1984), a similar variability in immediate PGFM responses of pregnant heifers was observed. Their conclusion was that the animals exhibiting the greater responses were those in which the embryo had given a reduced or inadequate antiluteolytic signal. Such an interpretation could therefore also be made for the present results, particularly as the amplitudes of the PGFM responses in 2 of the pregnant heifers were indistinguishable from those of non-pregnant animals (see Fig. 3). It seems likely that variability of the intensity of the antiluteolytic signal does occur, because of the variability of development that occurs in Day 16 embryos (Gustaffson \& Ploen, 1986). Also, at least in the sheep, there is a rapid increase in the rate of oTP-1 secretion as embryonic expansion occurs (Ashworth, 1987). As the 16th day of pregnancy is the time by which the antiluteolytic message must be received by the mother, if luteolysis is to be inhibited (Northey \& French, 1980), any retardation of embryonic development would be expected to result in a relative inadequacy of this crucial signal. This would in turn permit increased PGF-2 $\alpha$ secretion in response to oxytocin on Day 18.

Uterine oxytocin receptor concentrations were significantly higher in non-pregnant than pregnant heifers $(P<0.05)$. Similar results have been reported for multiparous cows (Jenner et al., 1990) and ewes (Sheldrick \& Flint, 1985). Surprisingly, the magnitude of the PGFM responses was correlated with neither the oxytocin receptor concentration nor the plasma steroid concentrations in pregnant or non-pregnant heifers. This lack of relationship between oxytocin receptor concentrations and PGFM responses could indicate that the response is independent of absolute concentrations of oxytocin receptors; i.e. that once induced, the oxytocin receptor exerts only a permissive role, with a low level of occupancy needed for maximal PGF- $2 \alpha$ response. Hence, a reduced availability of releasable oxytocin would also be required to prevent episodic PGF- $2 \alpha$ secretion; a feature of early pregnancy that has been noted in the ewe (Sheldrick \& Flint, 1983), although no similar data exist from the cow.

Endometrial oxytocin receptor concentrations were positively correlated with the circulating concentrations of oestradiol on Day $17(P<0.01$; Fig. 4) and inversely related to those of progesterone on Day $18(P<0.01$; Fig. 5). These results, and the fact that combining Day-17 oestrogen and Day-18 progesterone concentrations in a partial regression expression provided no better explanation of the data than did Day-17 oestradiol concentrations alone, would seem to confirm that oestrogens are of major importance in controlling oxytocin receptor development. The inhibition of progesterone secretion therefore appears to occur as a consequence, rather than a cause, of oxytocin receptor appearance. Few detailed studies exist of plasma oestradiol concentrations in early pregnant cattle, although Schallenberger et al. (1989) did report lower concentrations in the vena cava of pregnant compared to cyclic cows, with the nadir occurring on Day 21 of pregnancy. The lower oestradiol concentrations in early pregnancy could therefore be of importance in the inhibition of oxytocin receptor development that is characteristic of pregnancy. The mechanism by which oestrogen secretion and, presumably, follicular development are themselves inhibited is unclear, but could depend upon bTP-1-induced effects, or upon the oestrogen: progesterone ratio in the mid-luteal phase. 
Concentrations of PGF-2 $\alpha$, PGFM and PGE-2 in uterine flushings were similar to those previously reported from this laboratory (Shelton et al., 1990) and were higher $(P<0.001 ; P<0.05 ; P<0.01)$ in pregnant than non-pregnant animals. Although the finding of high levels of PGF-2 within the uterine lumen could suggest intraluminal sequestration, such as occurs in the pig (see Bazer \& First, 1983), it is more likely that the source of the prostaglandins was embryonic synthesis (Shemesh et al., 1979), as sequestration has not been demonstrated in the cow (Williams et al., 1983). Also, the observed lack of relationship between plasma PGFM responses to oxytocin challenge and intraluminal PGF-2 $\alpha$ concentrations would not be expected if sequestration were to occur in pregnancy. In the case of PGE-2, endometrial (Vincent \& Inskeep, 1986) and embryonic (Shemesh et al., 1979) secretion probably both contribute to intraluminal concentrations.

We thank Mr J. C. Starritt and Mr R. Temple for technical assistance and Hoechst UK Ltd for the gift of oxytocin. This study received financial support from the D. R. Melrose Memorial Trust (T.J.P.) and the AFRC.

\section{References}

Ashworth, C.J. (1987) Relationship between ovine conceptus and endometrial secretory proteins. Biol. Reprod. 36, Suppl. 1, 42, abstr

Bazer, F.W. \& First, N.L. (1983) Pregnancy and parturition. J. Anim. Sci. 57, Suppl. 2, 425-451.

Betteridge, K.J., Randall, G.C.B., Eaglesome, M.D. \& Sugden, R.P. (1984) The influence of pregnancy on PGF-2 $\alpha$ secretion in cattle. I. Concentrations of $15-$ keto-13,14-dihydro prostaglandin F-2 $\alpha$ and progesterone in peripheral blood of recipients of transferred embryos. Anim. Reprod. Sci. 7, 195-216.

Fincher, K.B., Hansen, P.J., Thatcher, W.W., Roberts, R.M. \& Bazer, F.W. (1984) Ovine conceptus secretory proteins suppress induction of PGF-2 $\alpha$ release by estradiol and oxytocin. J. Anim. Sci. 59, Suppl. 1, 545, abstr.

Flint, A.P.F. \& Sheldrick E.L. (1982) Ovarian secretion of oxytocin is stimulated by prostaglandin. Nature, Lond. 297, 587-588.

Glencross, R.G. \& Pope, G.S. (1981) Concentrations of oestradiol-17 $\beta$ in the plasma of dairy heifers before and after cloprostenol-induced and natural luteolysis and during early pregnancy. Anim. Reprod. Sci. 4, 93-106.

Glencross, R.G., Abeywardene, S.A., Corney, S.J. \& Morris, H.S. (1981) The use of oestradiol-17 $\beta$ antiserum covalently coupled to sepharose to extract oestradiol-17 $\beta$ from biological fluids. J. Chromat. 223, 193-197.

Gustaffson, H. \& Ploen, L. (1986) The morphology of 16 and 17 day old bovine biastocysts from virgin and repeat breeder heifers. Anat. Histol. Embryol. 15, 277-287.

Hunter, M.G., Southee, J.A., McLeod, B.J. \& Haresign, W. (1986) Progesterone pretreatment has a direct effect on GnRH-induced preovulatory follicles to determine their ability to develop into normal corpora lutea in anoestrous ewes. J. Reprod. Fert. 76, 349-363.

Jenner, L.J., Parkinson, T.L. \& Lamming, G.E. (1990) Uterine oxytocin receptor in the cyclic and pregnant cow. J. Reprod. Fert. (in press).
Kaker, M.L., Murray, R.D. \& Dobson, H. (1984) Plasma hormone changes in cows during induced or spontaneous calvings and the early post-partum period. Vet. Rec. 115, 378-382.

Kelly, R.W., Deam, S., Cameron, M.J. \& Seamark, R.F. (1986a) Measurement by radioimmunoassay of prostaglandins as their methyl oximes. Prostaglandins, Leukotrienes and Medicine 24, 1-14.

Kelly, R.W., Healy, D.L., Cameron, M.J., Cameron, I.T. \& Baird, D.T. (1986b) The stimulation of prostaglandin production by two antiprogesterone steroids in human endometrial cells. J. clin. Endocr. Metab. 62, 1116-1123.

Knickerbocker, J.J., Thatcher, W.W., Bazer, F.W., Barron, D.H. \& Roberts, R.M. (1986) Inhibition of uterine PGF- $2 \alpha$ production by conceptus secretory proteins. Prostaglandins 31, 777-793.

Lacroix, M.C. \& Kann, G. (1986) Aspects of the antiluteolytic activity of the conceptus during early pregnancy in ewes. J. Anim. Sci. 63, 1449-1458.

Lafrance, M. \& Goff, A.K. (1985) Effects of pregnancy on oxytocin-induced release of prostaglandin $\mathrm{F}-2 \alpha$ in heifers. Biol. Reprod. 33, 1113-1119.

Lukaszewska, J. \& Hansel, W. (1980) Corpus luteum maintenance during early pregnancy in the cow. $J$. Reprod. Fert. 59, 485-493.

McCracken, J.A., Schramm, W. \& Okulicz, W.C. (1984) Hormone receptor control of pulsatile secretion of PGF- $2 \alpha$ from the ovine uterus during luteolysis and its abrogation in early pregnancy. Anim. Reprod. Sci. 7, 31-53.

Nancarrow, C.D., Evison, B.M. \& Connell, P.J. (1982) Effects of embryos on luteolysis and termination of early pregnancy in sheep with cloprostenol. Biol. Reprod. 26, 263-269.

Northey, D.L. \& French, L.R. (1980) Effect of embryo removal and intra-uterine infusion of embryonic homogenates on the life-span of the bovine corpus luteum. J. Anim. Sci. 50, 298-302.

Schallenberger, E., Schams, D. \& Meyer, H.H.D. (1989) Sequences of pituitary, ovarian and uterine hormone secretion during the first 5 weeks of 
pregnancy in dairy cattle. J. Reprod. Fert., Suppl. 37, 277-286.

Sheldrick, E.L. \& Flint, A.P.F. (1981) Circulating concentrations of oxytocin during the estrous cycle and early pregnancy in sheep. Prostaglandins 22 , 631-635.

Sheldrick, E.L. \& Flint, A.P.F. (1983) Luteal concentrations of oxytocin decline during early pregnancy in the ewe. J. Reprod. Fert. 68, 477-480.

Sheldrick, E.L. \& Flint, A.P.F. (1984) Ovarian oxytocin and luteal function in the early pregnant sheep. Anim. Reprod. Sci. 7, 101-113.

Sheldrick, E.L. \& Flint, A.P.F. (1985) Endocrine control of uterine oxytocin receptors in the ewe. $J$. Endocr. 106, 249-258.

Sheldrick, E.L. \& Flint, A.P.F. (1986) Transient uterine refractoriness after oxytocin administration in ewes. J. Reprod. Fert. 77, 523-529.

Shelton, K., Parkinson, T.J., Hunter, M.G., Kelly, R.W. \& Lamming, G.E. (1990) Prostaglandin E-2 as a potential luteotrophic agent during early pregnancy in cattle. $J$. Reprod. Fert. 90, 11-17.

Shemesh, M., Milaguir, F., Ayalon, N. \& Hansel, W. (1979) Steroidogenesis and prostaglandin synthesis by cultured bovine blastocysts. J. Reprod. Fert. 56, $181-185$.

Thatcher, W.W., Wolfenson, D., Curl, J.S., Rico, L.E., Knickerbocker, J.J., Bazer, F.W. \& Drost, M. (1984) Prostaglandin dynamics associated with develop- ment of the bovine conceptus. Anim. Reprod. Sci. 7 , 149-176.

Thatcher, W.W., Hansen, P.J., Gross, T.S., Helmer, S.D., Plante, C. \& Bazer, F.W. (1989) Antiluteolytic effects of bovine trophoblast protein-1. J. Reprod. Fert., Suppl. 37, 91-99.

Vincent, D.L. \& Inskeep, E.K. (1986) Role of progesterone in regulating utero-ovarian venous concentrations of PGF-2 $\alpha$ and PGE-2 during the estrous cycle and early pregnancy in ewes. Prostaglandins 31, 715-733.

Webb, R., Mitchell, M.D., Falconer, J. \& Robinson, J.S. (1981) Temporal relationship between peripheral plasma concentrations of oxytocin, progesterone and 13,14-dihydro-15-keto PGF-2 $\alpha$ during the oestrous cycle and early pregnancy in the ewe. Prostaglandins 22, 443-451.

Williams, W.F., Lewis, S.G., Thatcher, W.W. \& Underwood, C.S. (1983) Plasma 13,14-dihydro-15keto PGF-2 $\alpha$ in pregnant and non-pregnant heifers prior to and during surgery and following intrauterine injection of PGF-2 $\alpha$. Prostaglandins 25, 891-899.

Wolfenson, D., Thatcher, W.W., Drost, M., Caton, D., Foster, D.B. \& LeBlanc, M.M. (1985) Characteristics of prostaglandin $\mathrm{F}$ measurements in ovarian circulation during the oestrous cycle and early pregnancy in the cow. J. Reprod. Fert. 75, 491-499.

Received 15 February 1990 